\title{
2. TECTONIC FABRIC OF THE SEAFLOOR NEAR NORTH CENTRAL ATLANTIC DRILL SITES 1
}

\author{
S. C. Cande, Lamont-Doherty Geological Observatory \\ R. C. Searle, Institute of Oceanographic Sciences \\ and \\ I. Hill, University of Leicester ${ }^{2}$
}

\section{INTRODUCTION}

The nine sites drilled during Leg 82 are located along four flow lines that run perpendicular to the Mid-Atlantic Ridge (MAR). Together with Site 335 (Leg 37), these sites form a grid that samples the ocean basement along two isochrons, 17 and $35 \mathrm{Ma}$ old, parallel to the ridge crest. The criteria used in selecting the sites was that the ocean basement should be "typical" of normal Mid-Atlantic Ridge terrain. "Typical" means that the basement has a lineated character, with the grain running parallel to the ridge (Atwater, 1979). This lineated character is best seen in side-scan images (e.g., Searle and Laughton, 1977; Laughton and Searle, 1979) or SEABEAM maps of the ocean floor. The only exception to the criteria of drilling on typical MAR terrain was made at Site 557 , which was purposefully located on a flat-floored basin.

In this paper we present the geophysical data that exists in the region of each site drilled during Leg 82 . These sites were not surveyed before drilling. Instead, the sites were selected based on the existing underway geophysical data in the Lamont-Doherty Geological Observatory and Woods Hole data libraries at the time of the cruise. Some of these data had been compiled before the cruise as part of the Ocean Margin Drilling (OMD) Area 11 data synthesis effort. Preliminary copies of the OMD bathymetric and magnetic maps for the region south of $38^{\circ} \mathrm{N}$ were used in selecting the sites. Following the cruise, Sites 556 through 562 were surveyed by R. C. Searle using the Gloria side-scan sonar system aboard the Farnella. In addition, copies of data collected near Site 558 by W. van der Linden on board the Canadian Research Vessel Baffin were made available to us after the cruise. We will combine all of these data in order to more fully describe the tectonic setting of the Leg 82 sites.

\section{THE AZORES AND FAMOUS FLOW LINES}

The two northern flow lines straddle the Pico Fracture Zone. An index map for the geophysical data on the northern flow lines is shown in Figure 1. Bathymet-

\footnotetext{
${ }^{1}$ Bougault, H., Cande, S. C., et al., Init. Repts. DSDP, 82: Washington (U.S. Govt. Printing Office).

Addresses: (Cande) Lamont-Doherty Geological Observatory, Palisades, New York 10964: (Searle) Institute of Oceanographic Sciences, Wormley, Surrey, United Kingdom; (Hill) Department of Geology, University of Leicester, Leicester, United Kingdom.
}

ric and magnetics data for this region are shown in Figures 2 and 3 , respectively. A seismic reflection profile available along the Azores flow line before the cruise is shown in Figure 4. Additional seismic reflection data available before the cruise consisted of a profile along the Knorr $(K n 311)$ track in Figure 1 passing near Site 558. Seismic reflection data collected on the Glomar Challenger while moving between sites are shown in Figure 5. The interpretations of the Gloria sonographs presented below were made by R. C. Searle.

Technical details and principles of Gloria interpretation are given in Searle and Laughton (1977). In this paper, we interpret the brightest reflections on the Gloria sonographs as probably coming from basement outcrops; we believe that less bright, but still relatively strong, reflections arise from steeply sloping, possibly winnowed, pelagic sediments draping abyssal hills, although this interpretation is more tentative. During the surveys of Sites 556 through 558, the resolution of Gloria was degraded by a technical fault. The system was working normally for the other surveys.

\section{Site $\mathbf{5 5 6}$}

The drilling strategy decided upon before the cruise dictated that the first site would be drilled north of the Pico Fracture Zone near Anomaly 13. The seismic reflection data from Vema Cruise 32, shown in Figure 4, indicated that this was a region of typical Mid-Atlantic Ridge topography. The preliminary location of the site was based on the magnetics data from the Atlantis II (AII-49), Bowditch (BD63), and Snellius (Snll) cruises on which Anomaly 13 was identified striking north-south near $35^{\circ} \mathrm{W}$. Although Anomaly 13 was poorly formed on the Bowditch profile, it was easily identified on the Challenger magnetometer data as the site was crossed.

The Gloria data (Fig. 6) confirm that the topography in this region is typical of normal MAR terrain, with strongly lineated north-south trending outcrops probably associated mainly with fault blocks. The nearest outcrops appear to be about 7 to $10 \mathrm{~km}$ south of the drill site and are quite small. There may be a few small, more rounded areas of outcrop in this region, but it is difficult to judge because of the degraded resolution in the sonar beam. The north-south striking basement outcrops observed about $25 \mathrm{~km}$ east of the drill site near $34^{\circ} 30^{\prime} \mathrm{W}$ correspond to the twin peaks observed at $0000 \mathrm{hr}$. on the Vema 32 profiler record. The north-south basement out- 


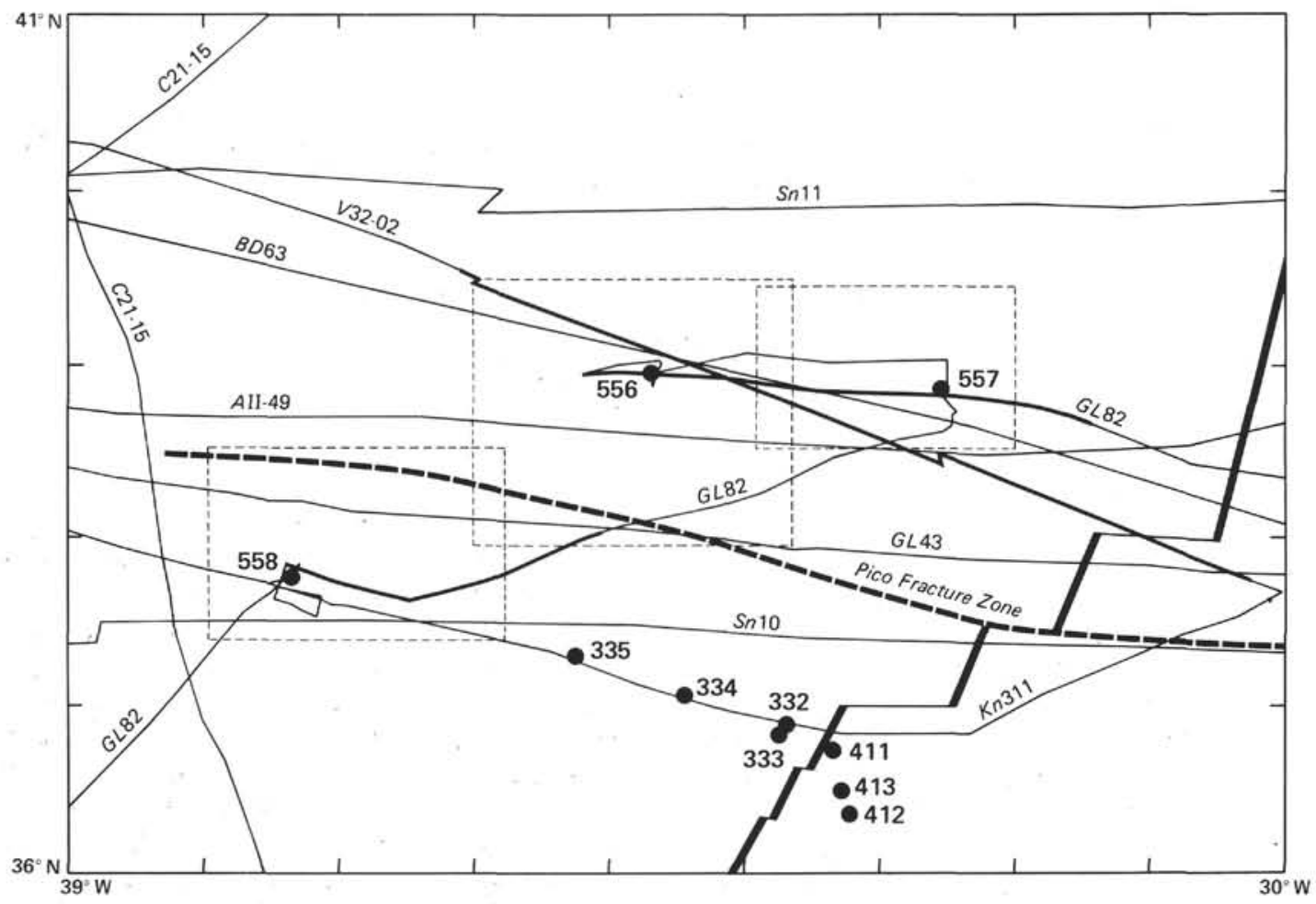

Figure 1. Identification of ships' tracks with geophysical data near Sites 556 through 558 (Azores and FAMOUS flow lines). Dashed boxes indicate location of Figures 6, 8, and 10 showing Gloria data. Heavy lines show portions of track with seismic profiler data displayed in Figures 4 and 5. Solid circles are DSDP sites. Ship identifications as follows: C21-15 = Conrad Cruise 21, Leg 15; V32-02 = Vema Cruise 32, Leg 02; AII-49 = Atlantis II, Leg 49; GL82= Challenger Leg 82; Sn11 = Snellius; BD63 = Bowditch; KN311 = Knorr .

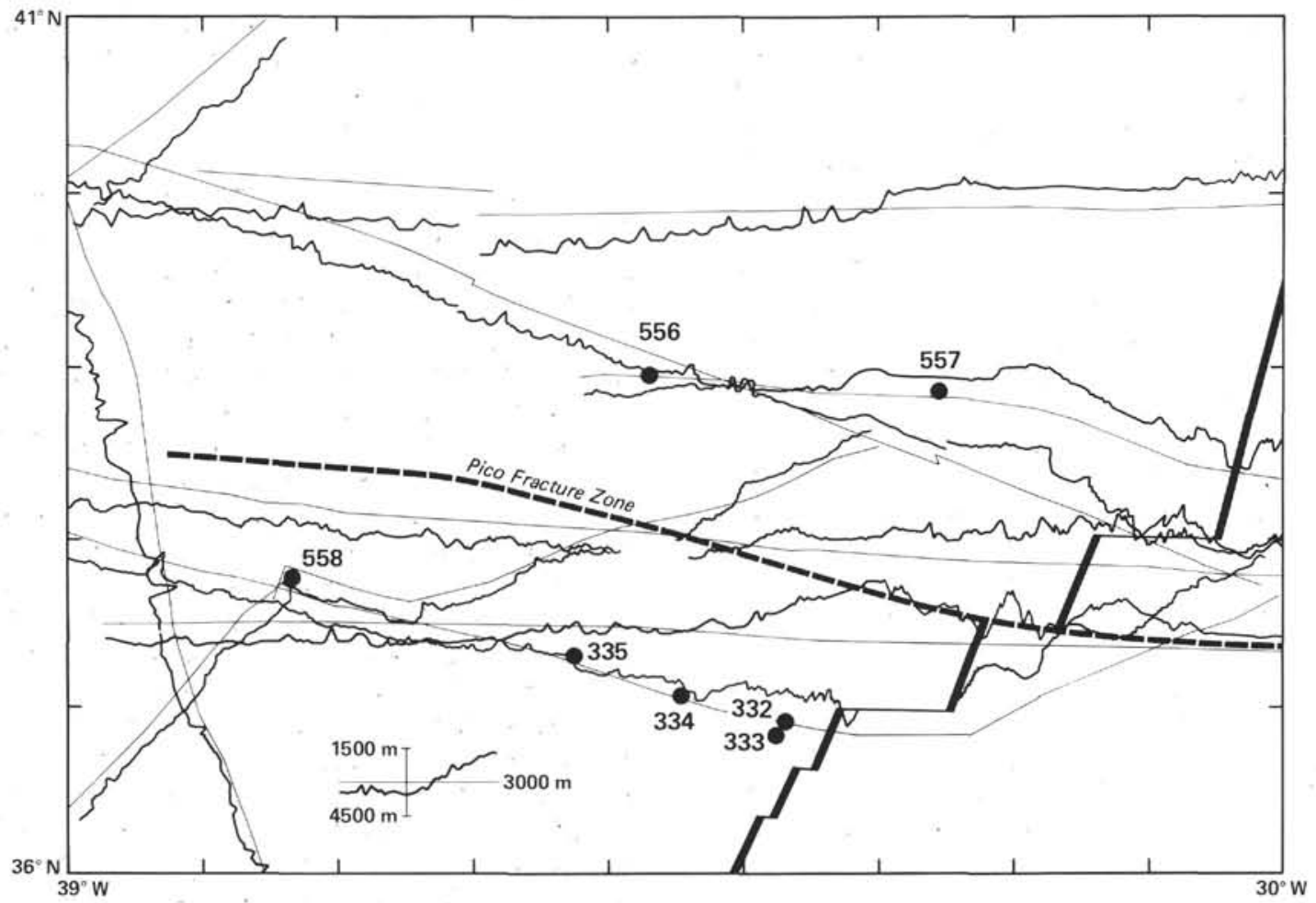

Figure 2. Bathymetry (Azores and FAMOUS flow lines) plotted as profiles perpendicular to the track. Solid circles are DSDP sites. 


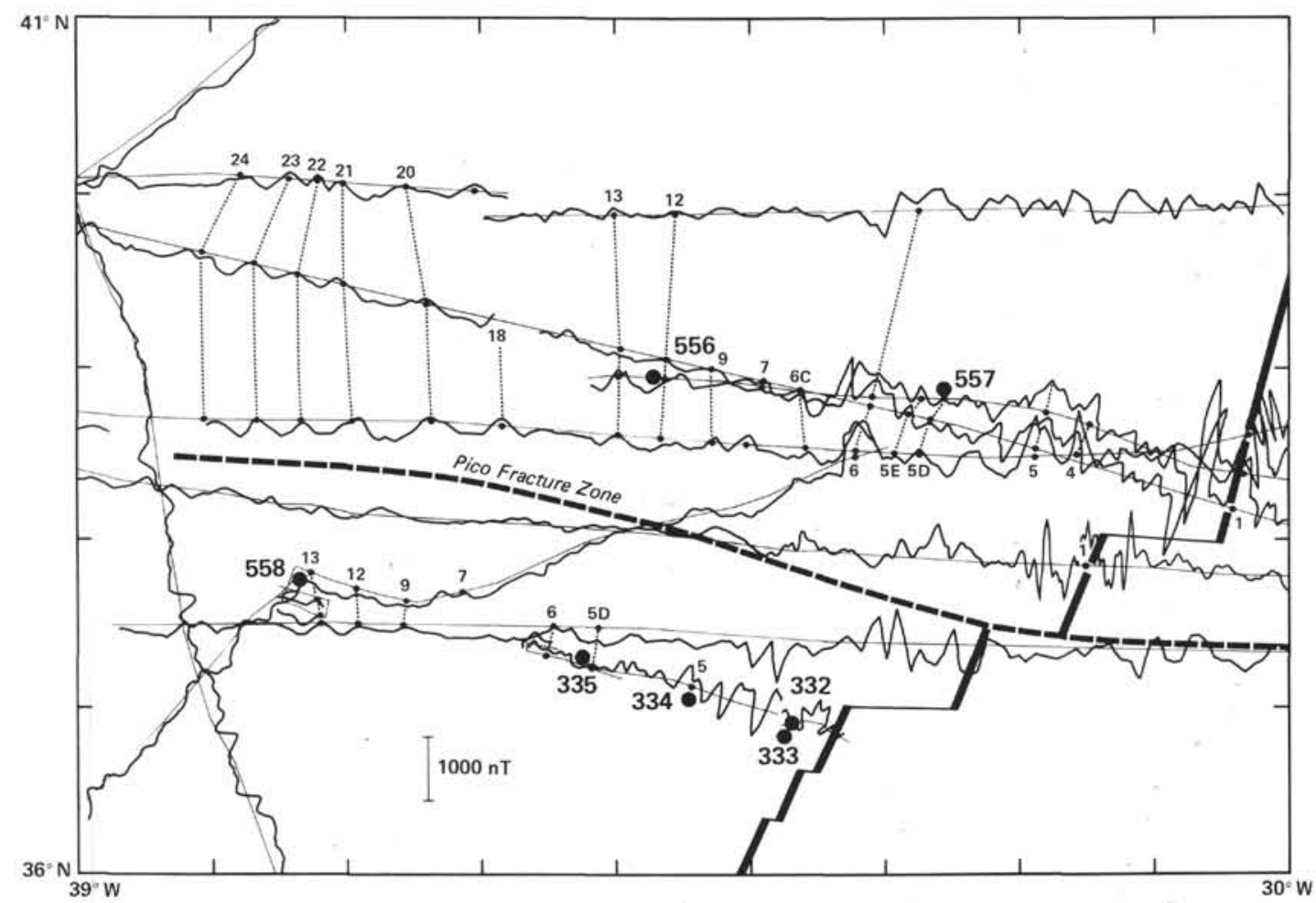

Figure 3. Residual magnetic anomaly field plotted perpendicular to the track. Solid circles are DSDP sites; other numbers are magnetic anomalies.

crops seen on the Gloria record near $34^{\circ} 00^{\prime} \mathrm{W}$ correspond to the peaks crossed at $0200 \mathrm{hr}$. on the Vema 32 profiler record (Fig. 4) and at $1900 \mathrm{hr}$. on the Glomar Challenger profile (top, Fig. 5).

\section{Site $\mathbf{5 5 7}$}

The preliminary planning for Site 557 was based on the Vema 32 seismic reflection line and the Bowditch (BD63) and Atlantis II (AII-49) magnetics data. These data showed that east of Anomaly 6 there was a $40-\mathrm{km}$ wide basin located on anomalously shallow and smooth basement. However, even through the basement structure is abnormal for the Mid-Atlantic Ridge, the magnetic anomalies (Fig. 3) are lineated and can be identified in the framework of magnetic reversal lineations. Site 557 was located on what was identified during the cruise as Anomaly 5D.

A model of the seafloor-spreading magnetic anomalies suggests that the initial anomaly identifications may be incorrect (Fig. 7). If the two prominent anomalies bordering the east and west side of the basin are identified as Anomalies 5 and 6, respectively, than a constant spreading rate shows that Site 557 may have been drilled on Anomaly 5B. Because the hole was washed to basement, and sediments were only recovered from a wash core, there is no reliable biostratigraphic constraint on the basement age. The oldest sediments in the wash core are dated as $13 \mathrm{Ma}$ old, which is roughly the age of Anomaly $5 \mathrm{~B}$. Fortunately, a change (or uncertainty) in age of the site has little effect on the interpretation of the drilling results.
The Gloria sonographs (Fig. 8) showed that there are hills within $5 \mathrm{~km}$ to the northwest and northeast of Site 557. These and most other structures visible within about $65 \mathrm{~km}$ of the site are only poorly lineated. Generally, areas of outcrop are equidimensional suggesting volcanic construction rather than tectonic relief. Indeed, it may be possible to discern two craters associated with the hills just north of the drill site. The existence of this presumed volcanic terrain is strongly consistent with the association of this area with mantle blob or hot-spot activity, as inferred from the basalt chemistry. Normally lineated seafloor occurs west of $33^{\circ} 30^{\prime} \mathrm{W}$ (Fig. 8), which is where the smooth basement gives way to normal rugged basement $(0500 \mathrm{hr}$. on the Vema 32 seismic profile, Fig. 4).

\section{Site 558}

The preliminary location of Site 558 was based on the Snellius (Sn10) magnetics and the Knorr (Kn311) seismic data (not shown). Although the basement around the site on the Knorr profile appeared to be representative of typical.MAR topography, the data collected on the Challenger while surveying the site showed that the tectonic fabric was atypical. The most obvious complexity was that the magnetic anomalies in the immediate vicinity of the site strike about $350^{\circ}$, oblique to the ridge crest. Additional magnetic data made available to us by W. van der Linden (pers. comm., 1983) and shown in Figure 9 document the varying trends of the magnetic anomalies in this area. Near Site 558, Anomalies 12 and 13 strike slightly west of North. Near the Pico Fracture 

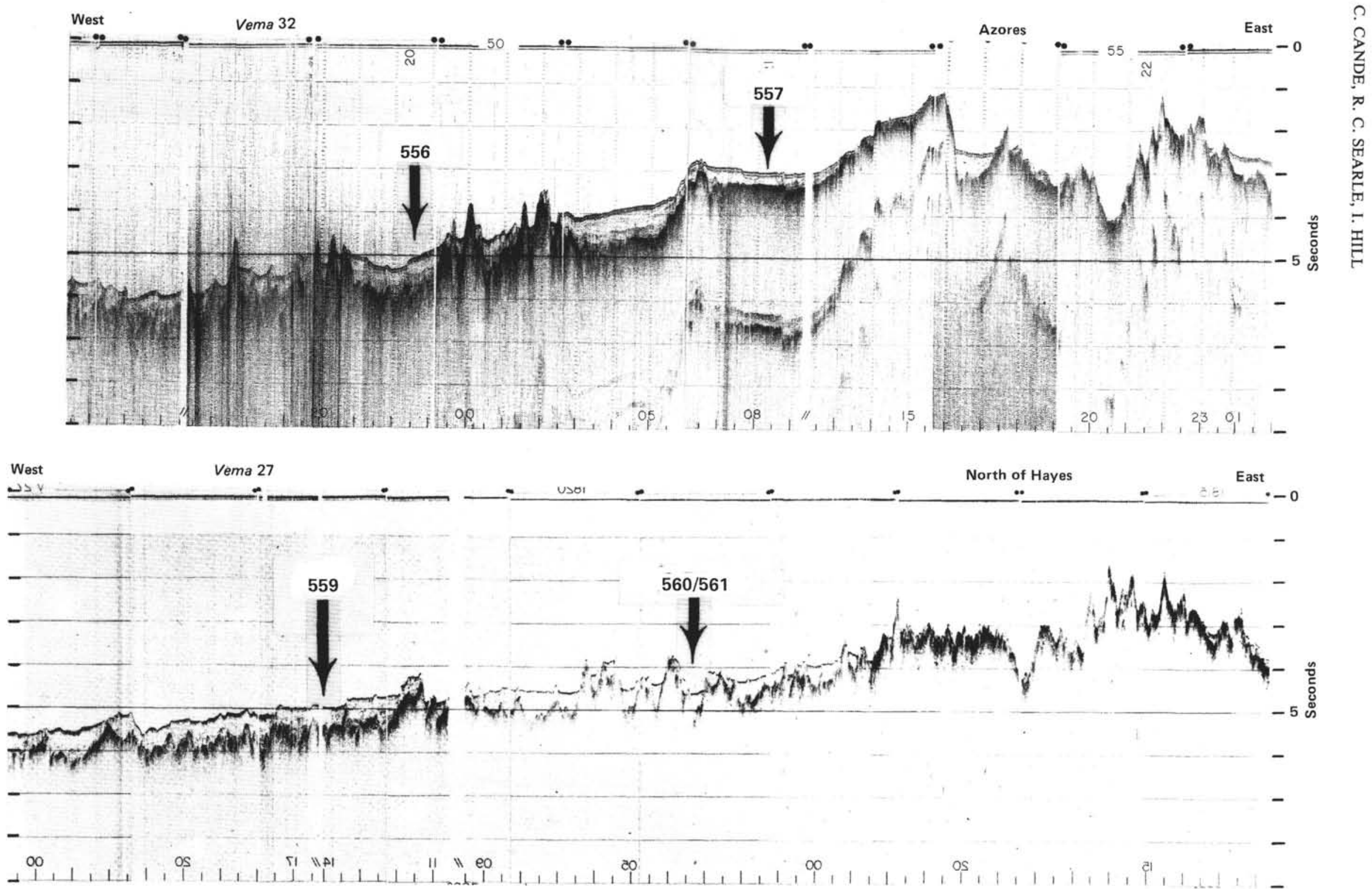

Figure 4. Seismic reflection data available from the library at Lamont-Doherty Geological observatory before Leg 82 . The closest approach of the ship's tracks to the drilled sites are indicated by arrows. 


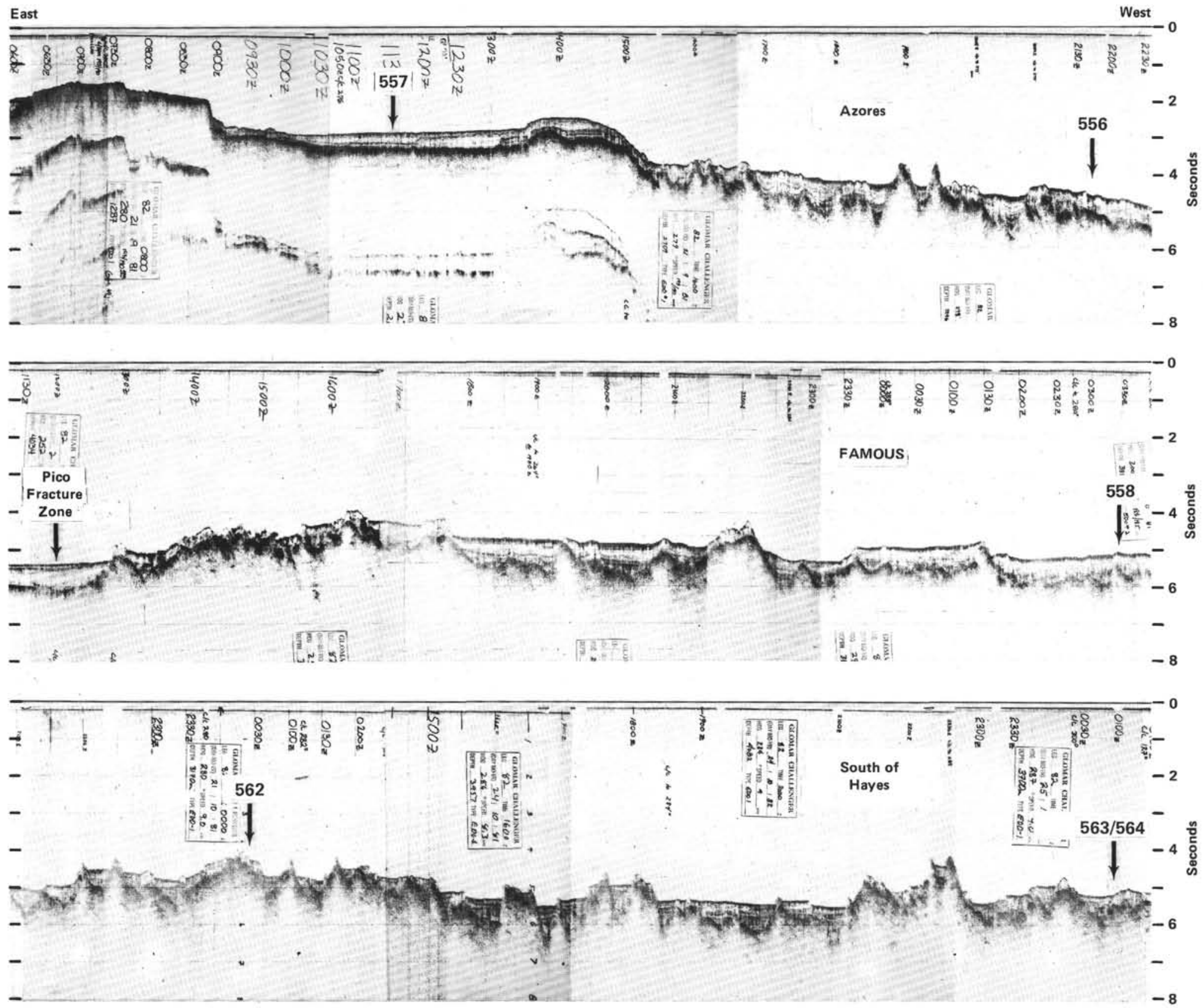




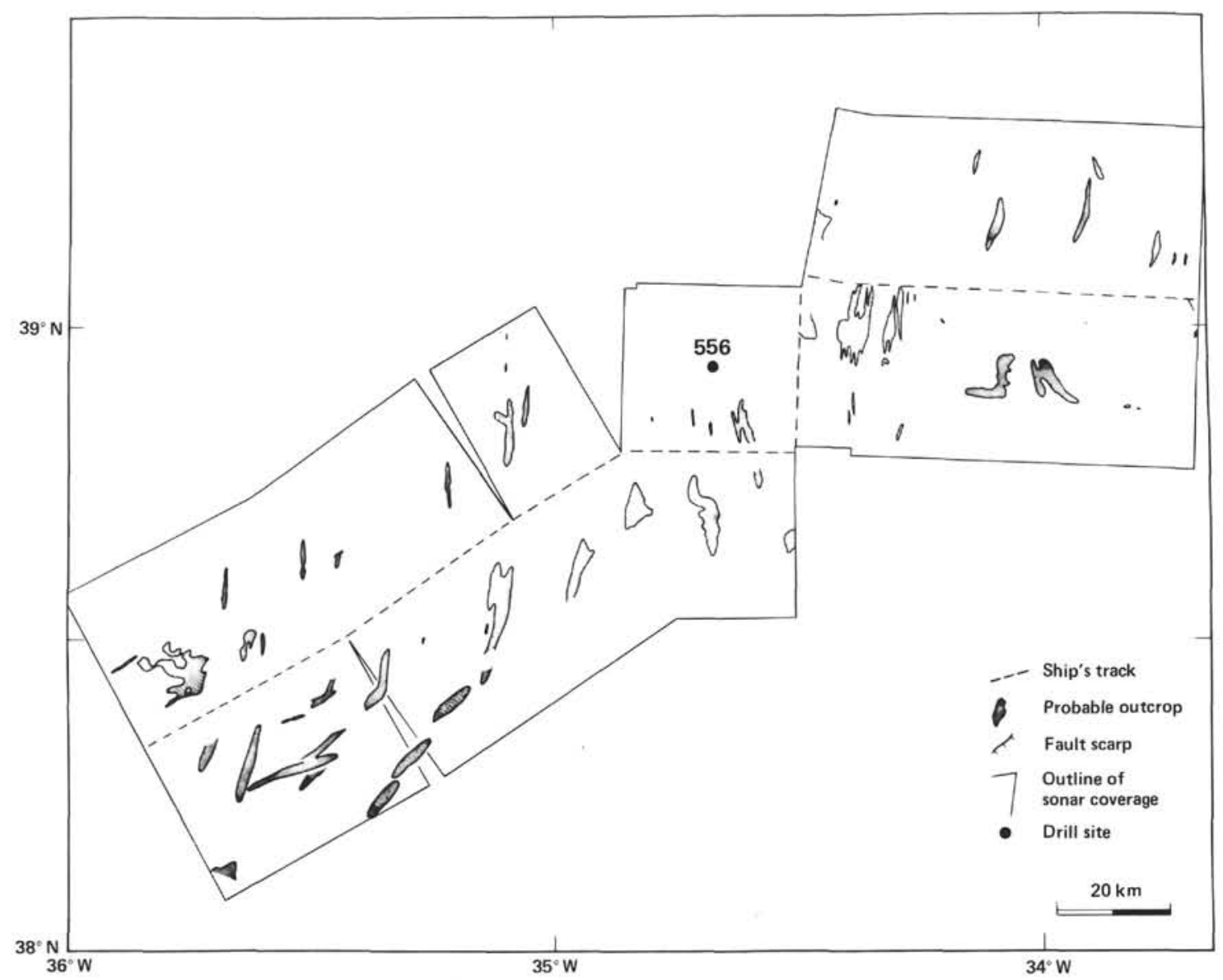

Figure 6. Interpretation of Gloria sonographs near Site 556.

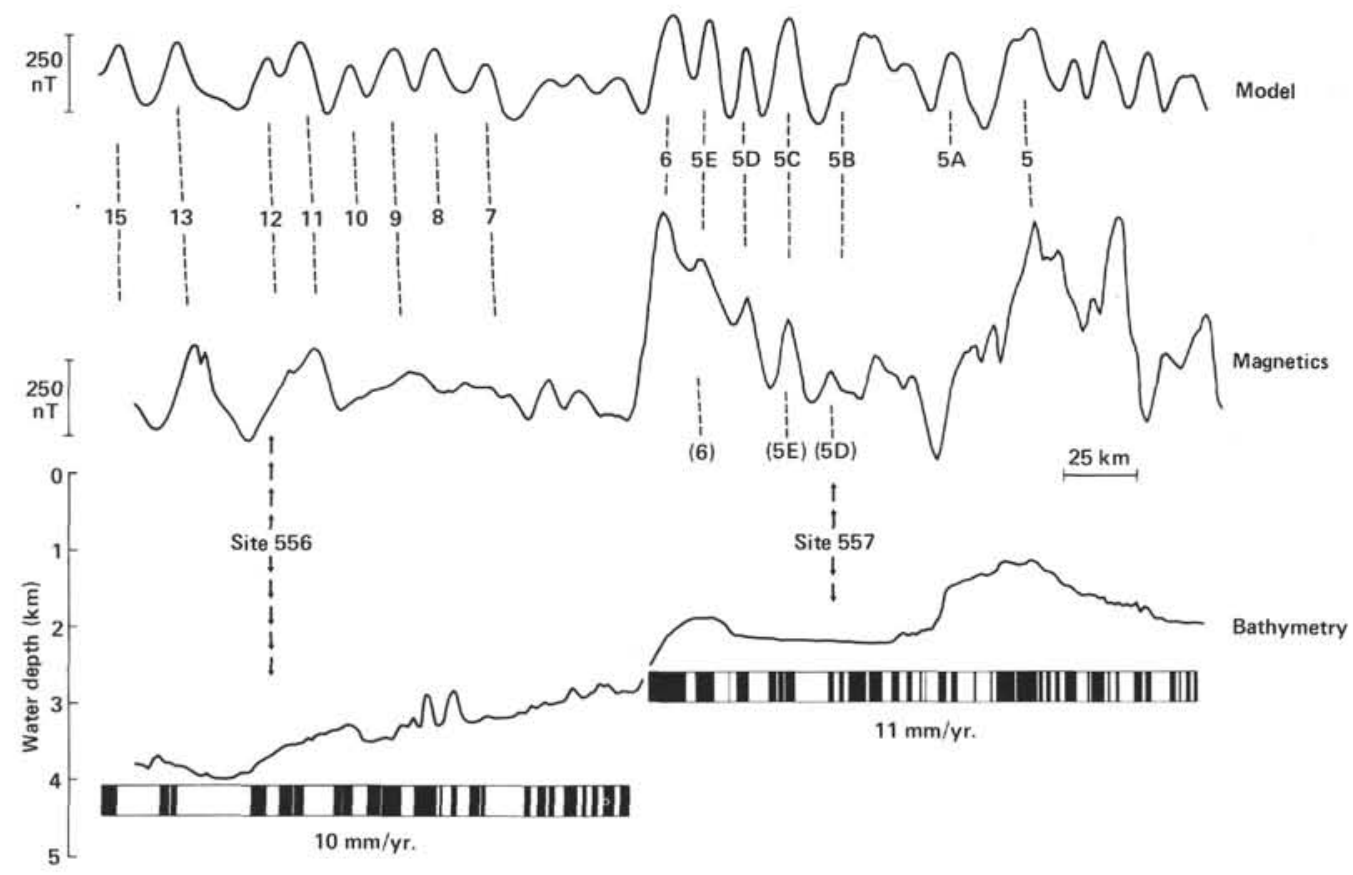

Figure 7. Bathymetry and magnetic data collected by the Challenger along the Azores flow line. Top line is a seafloor spreading magnetic anomaly model assuming the time scale of LaBrecque et al. (1977), a layer $500 \mathrm{~m}$ thick and a magnetization of $0.007 \mathrm{emu} / \mathrm{cm}^{3}$. This model suggests that Site 557 was drilled near Anomaly $5 \mathrm{~B}$. 


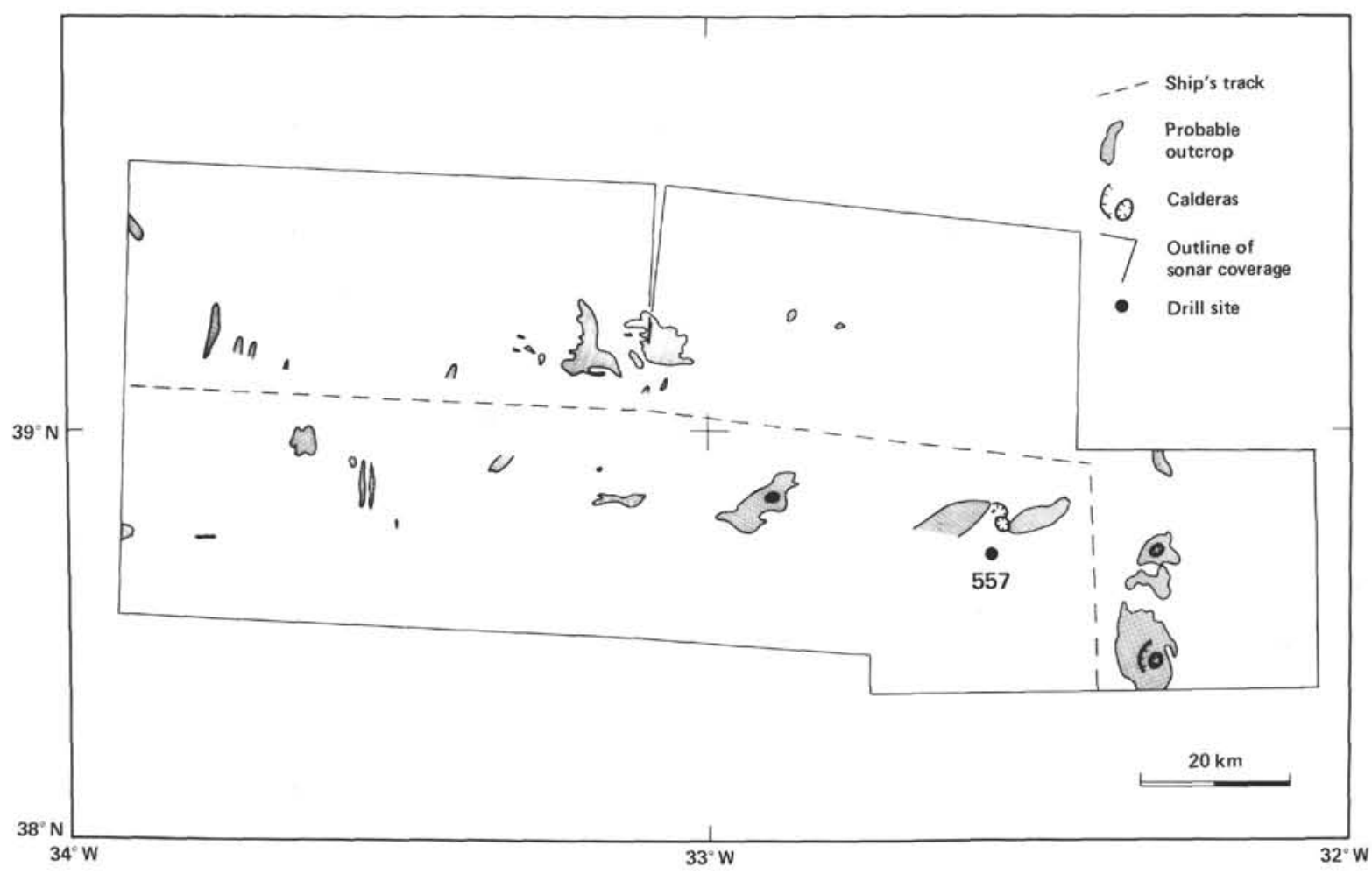

Figure 8. Interpretation of Gloria sonographs near Site 557.

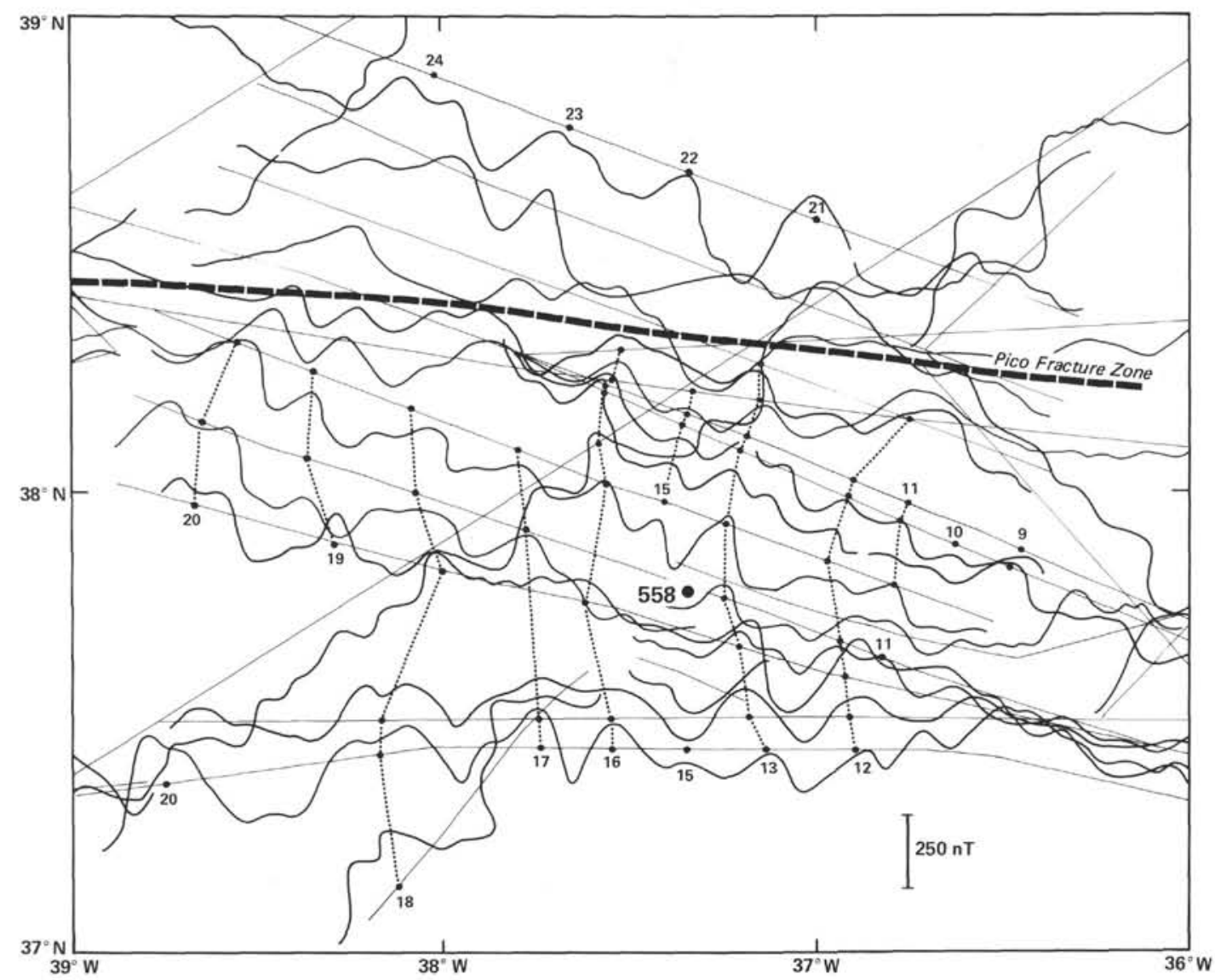

Figure 9. Magnetic anomaly data near Site 558 (with the exception of the Challenger data, these data were compiled by W. van der Linden). 
Zone; Anomalies 13, 15 , and 16 strike roughly $010^{\circ}$ whereas Anomaly 12 strikes about $040^{\circ}$.

The original shipboard identifications of the magnetic anomalies near Site 558 were in error. During the Challenger cruise, the prominent magnetic anomaly east of the site was identified as Anomaly 12 . However, based on the rotation of all anomalies west of the ridge back to the location of anomalies east of the ridge, Schouten (pers. comm., 1983) determined that the prominent anomaly east of the site was Anomaly 13. This new identification is supported by the large amount of data now available (Fig. 9).

The complexity of the basement trends is also seen in the Gloria data (Fig. 10). West of the drill site and east of it to about $37^{\circ} 20^{\prime} \mathrm{W}$, outcrops indicating the general tectonic fabric strike about $004^{\circ}$. Between $37^{\circ} 20^{\prime} \mathrm{W}$ and $36^{\circ} 45^{\prime} \mathrm{W}$, the trend is generally about $040^{\circ}$. Some of these northwest-southwest lineaments border the Pico Fracture Zone and may have had their origin in the dextral offset transform that produced it, because such oblique features are characteristic of fracture zones (Searle, 1979). However, such features are normally confined to within $20 \mathrm{~km}$ of the fracture zone axis, whereas here oblique structures are seen up to $70 \mathrm{~km}$ south of the fracture zone. Another or additional explanation may be that they represent the results of a phase of oblique spreading such as occurred near the Oceanographer Fracture Zone before Anomaly 6 and since Anomaly 4 (Phillips et al., 1975). If oblique spreading is more likely during times of high plume discharge, as suggested for the Reykjanes Ridge by Vogt and Johnson (1975), these observations may indicate that such a discharge was immi- nent during formation of the crust at Site 558. This might account for some of the basalt chemical variability. The Pico Fracture Zone can be discerned on the sonographs near $38^{\circ} 15^{\prime} \mathrm{N}, 36^{\circ} 00^{\prime} \mathrm{W}$.

\section{THE SOUTHERN FLOW LINES}

The two southern flow lines straddle the Hayes Fracture Zone. The location of the geophysical lines used in selecting these sites and the location of the Gloria sonographs are shown in Figure 11. Bathymetric and magnetics data on tracks passing near the sites are shown in Figures 12 and 13, respectively. The Challenger seismic data from north of the Hayes Fracture Zone are shown in Figure 14. Interpretations of the Gloria sonographs from Sites 559-562 are presented in Figures 15, 17, and 19. The original montages of the Gloria records from these sites are shown in Figures 16, 18, and 20, respectively.

\section{Site $\mathbf{5 5 9}$}

Site 559 was located near Anomaly 13 on the flow line north of the Hayes Fracture Zone. The preliminary planning for the site was based on a Vema 27 seismic reflection profile (Fig. 4) that indicated that about $400 \mathrm{~m}$ of sediment cover normal-looking basement near Anomaly 13 . Existing magnetic anomaly data consisted of the Trident $(T 152)$ profile and the Vema 27 profile. The identifications of Anomalies 12 and 13 were straightforward (Fig. 13).

The Gloria sonographs (Figs. 15 and 16) showed that Site 559 was located $2 \mathrm{~km}$, northwest of a small abyssal hill. The hill is fault-bounded on its east-southeast side,

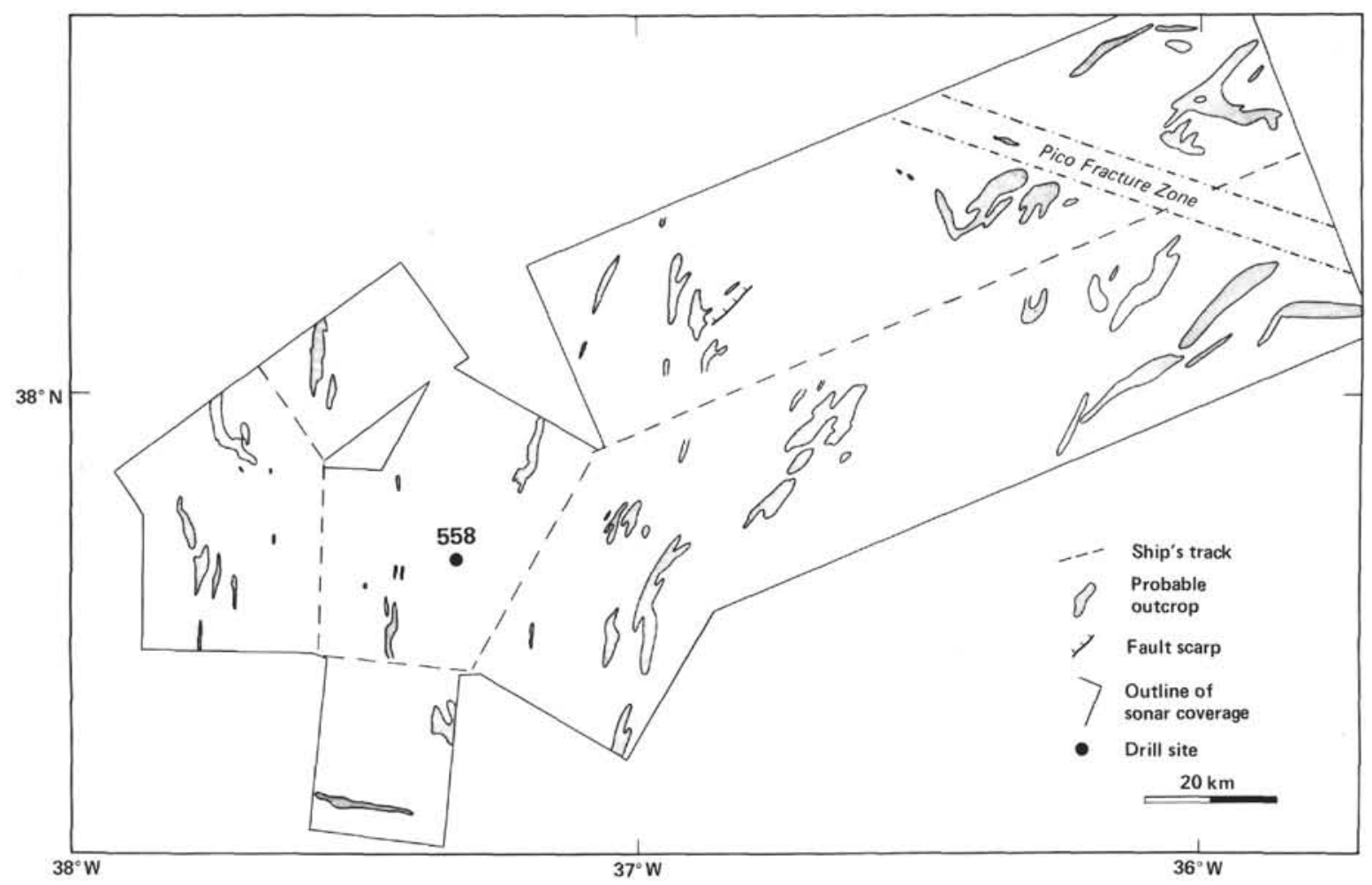

Figure 10. Interpretation of Gloria sonographs near Site 558. 


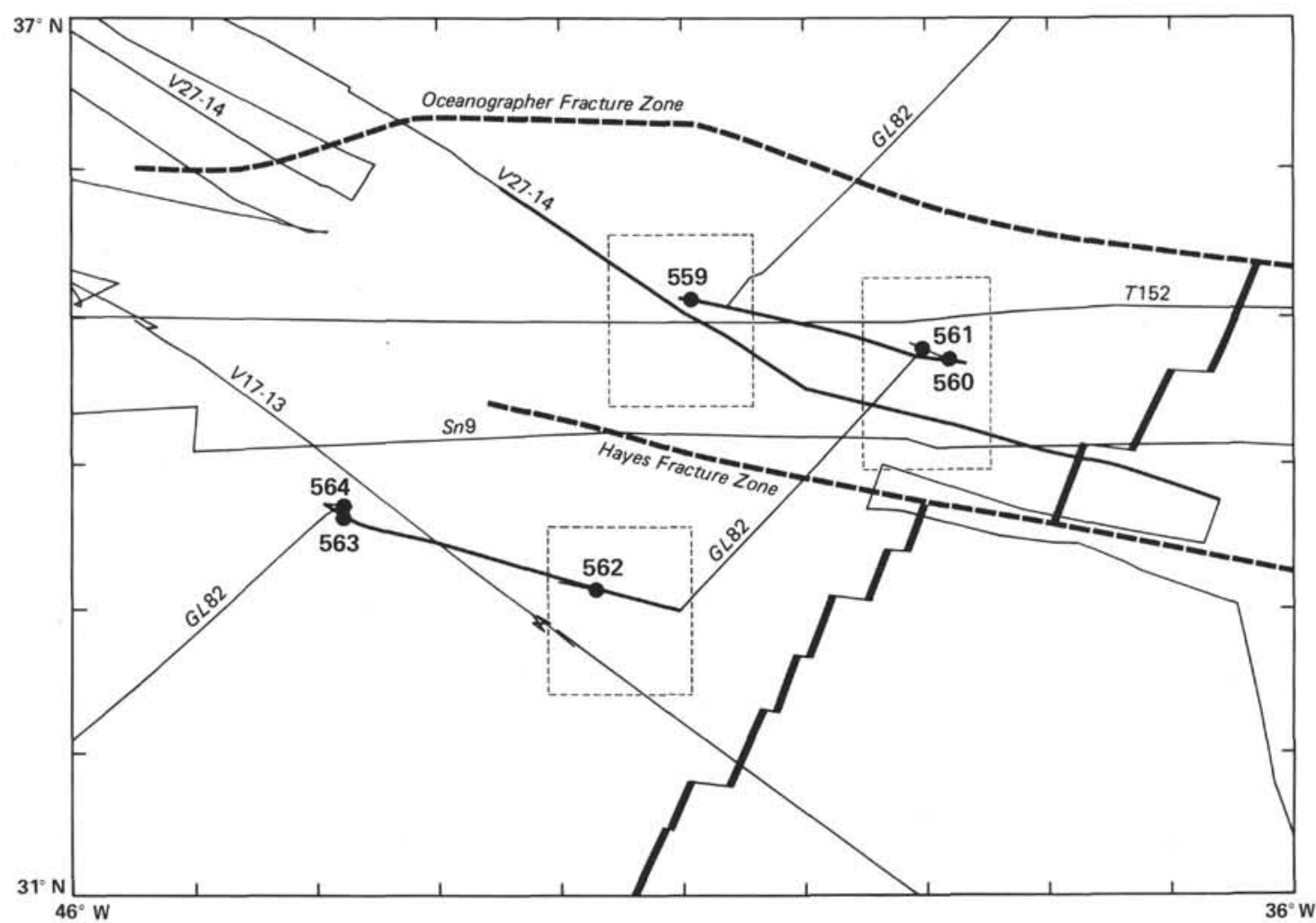

Figure 11. Identification of ships' tracks near Sites 559 through 564. Dashed boxes show location of Figures 15-20 which contain Gloria data. Solid circles are DSDP sites. For ship identifications, see Fig. 1; also T152 = Trident Cruise 152.

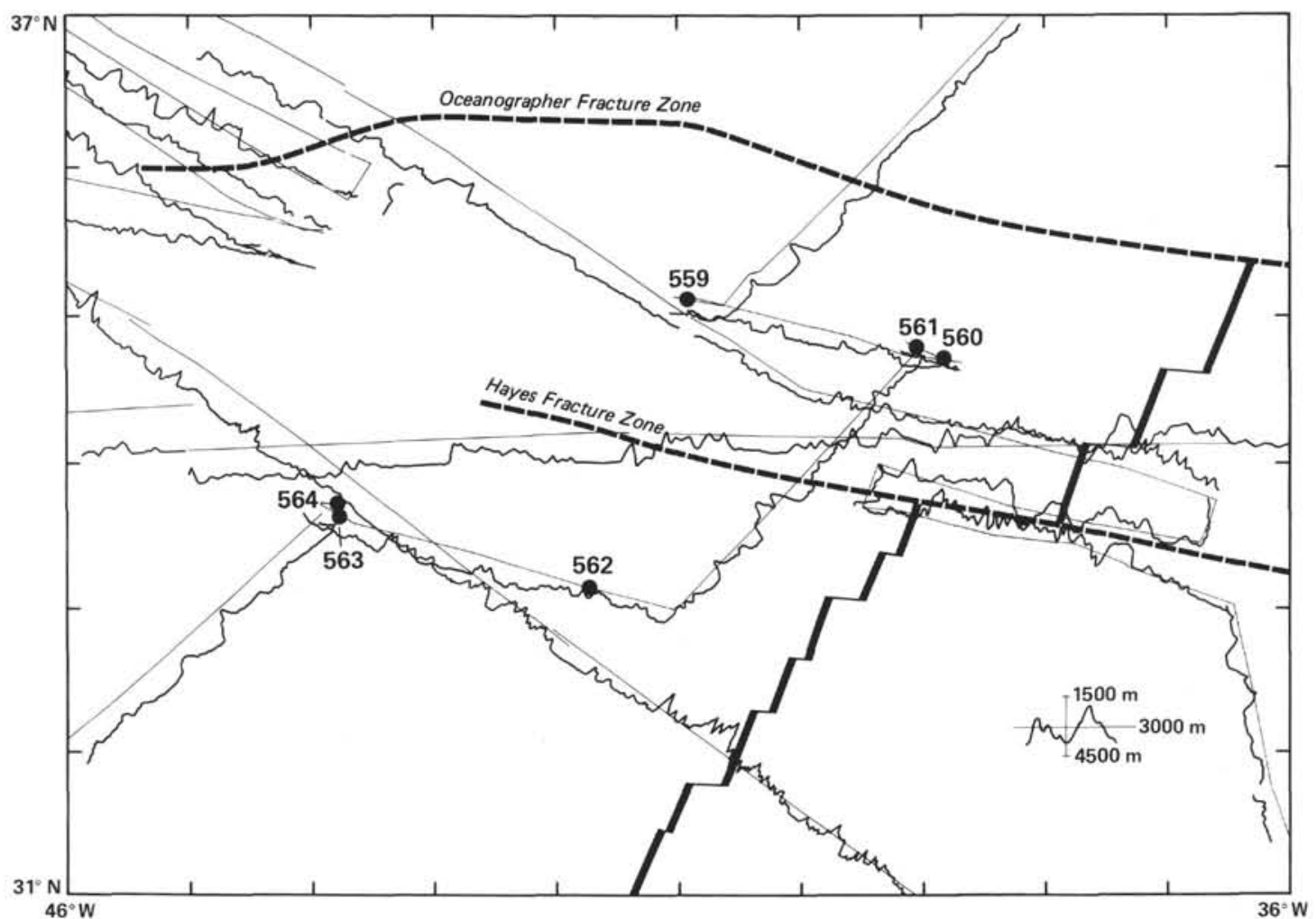

Figure 12. Bathymetric data plotted as profiles perpendicular to the track. Solid circles are DSDP sites. 


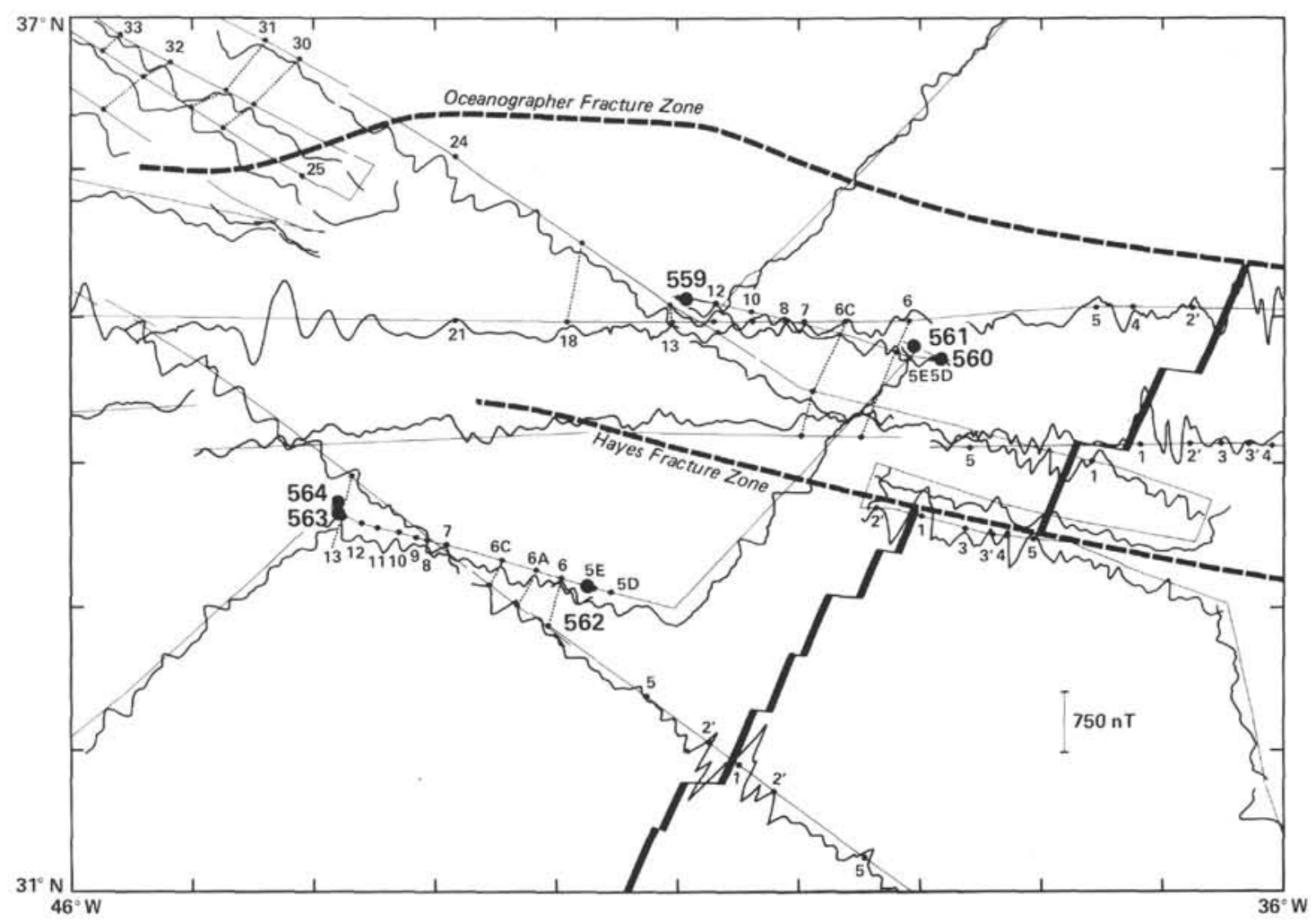

Figure 13. Residual magnetic anomaly data (Hayes Fracture Zone flow lines) plotted as profiles perpendicular to the track. Solid circles are DSDP sites; other numbers are anomalies.

but a dip slope faces the drill site. The hill displays several areas of probably thinly sedimented volcanic basement. Another small hill is situated $15 \mathrm{~km}$ northwest of the site.

The drill site appears to be situated in a region of normal tectonic fabric, exemplified by the tilted fault blocks striking north-northeast that make up the lineated abyssal hills. However, a small fracture zone, indicated by a $100-\mathrm{km}$-long series of outcrops trending eastwest passes about $60 \mathrm{~km}$ to the south of the site.

\section{Sites 560 and 561}

Site 560 was located near Anomaly 5D along the same flow line as Site 559. The closest seismic profiler record was from Vema $27(V 27-14)$ (Fig. 4) and the nearest magnetic data were from Trident $(T 152)$. Anomaly 6 is easy to identify on both the Vema and Trident tracks. The seismic reflection data showed that the basement relief was typical of the Mid-Atlantic Ridge.

Very poor core recovery was achieved at Site 560, probably because the hole had been drilled through a talus slope facing the spreading axis. The Gloria data (Figs. 17 and 18) confirm this, showing that the site is situated less than $2 \mathrm{~km}$ to the east of an abyssal hill, which is bounded on its eastern side by an east-facing fault scarp. Basement appears to outcrop along this scarp.

Site 561 was drilled on Anomaly 5E, 10 miles northwest of Site 560. The Gloria data show that the site is situated in a $15 \mathrm{~km}$-wide basin between abyssal hills. The nearest hill is about $4 \mathrm{~km}$ east-southeast of the site.
Both Sites 560 and 561 appear to be in region of normal MAR volcanic and tectonic fabric. The abyssal hills are strongly lineated and aligned north-northeast-southsouthwest parallel to the magnetic isochrons. In a small Gloria survey carried out near the MAR axis on this same flow line (R. C. Searle, unpublished data), a relatively complicated tectonic fabric was found, with several short-offset fracture zones and some large volcanic massifs devoid of the normal lineated tectonic fabric (similar to those found at Site 557). There is no evidence of such massifs around Sites 560 and 561. However, the presence of two zones of outcrops trending east-northeast just $15 \mathrm{~km}$ north of Site 561, suggests a small fracture zone or zone of oblique spreading. Other outcrops trending east-northeast occur 60,75 , and $90 \mathrm{~km}$ south of Site 561, still north of Hayes Fracture Zone. It may be, therefore, as argued for Site 558, that the basalt variability is in some way related to a tendency to oblique spreading.

\section{Site 562}

Site 562 was located near Anomaly 5D south of the Hayes Fracture Zone. The only seismic data near the site before drilling was an early Vema 17 (V17-13) profile shot with explosives. Anomaly 6 was identified on the magnetic data from this cruise and was used to select the general location of the site. The seismic data collected on the Challenger (Fig. 5) showed that the basement in this area was normal in appearance.

Gloria is not very sensitive to small variations in seabed slope. The interpretation shown in Figure 19 was 
West

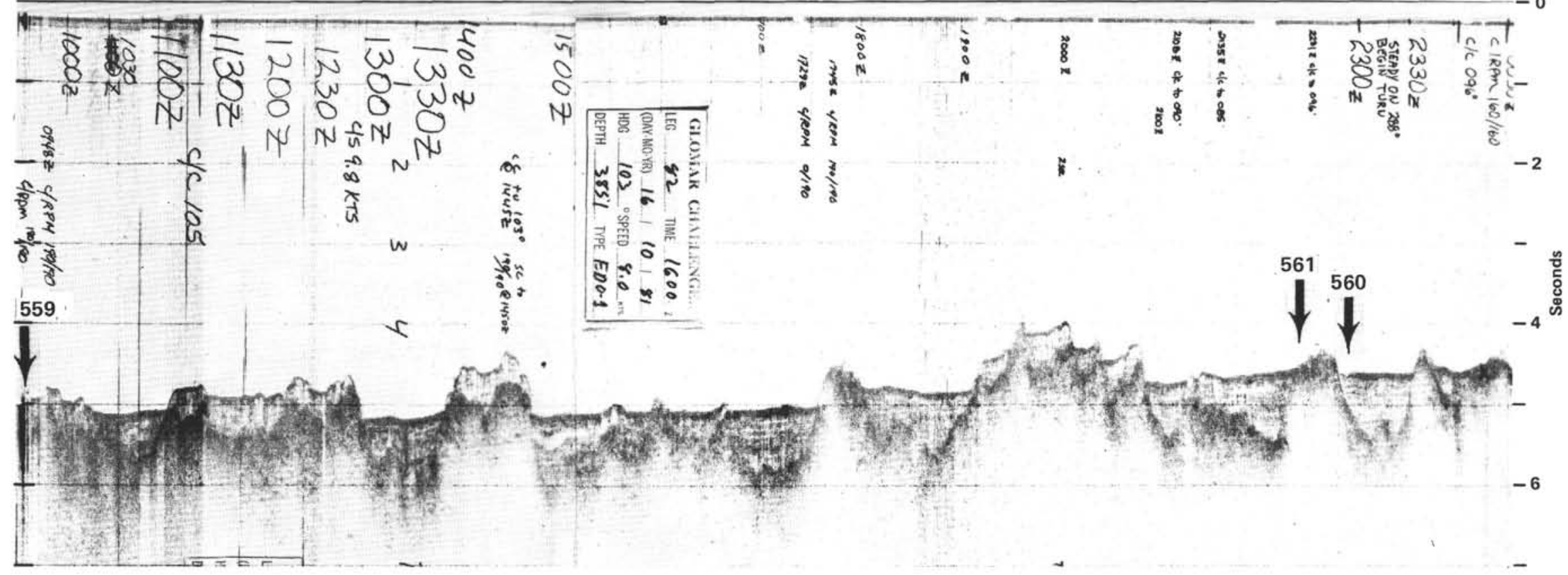

Figure 14. Seismic reflection data collected by the Challenger in transit between Sites 559 and 560 . 


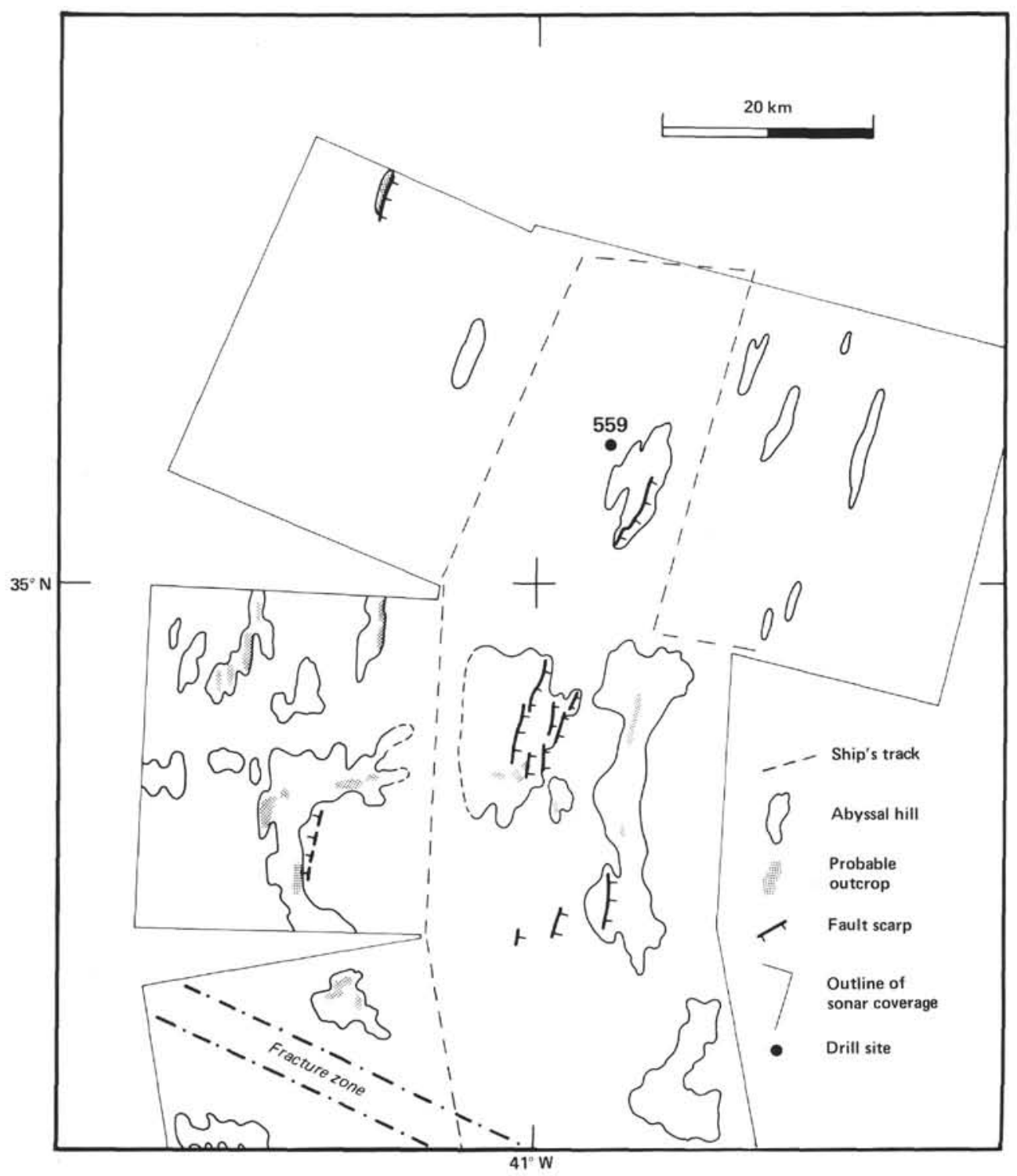

Figure 15. Interpretation of Gloria sonographs near Site 559.

done without benefit of the seismic profile (Fig. 5) and shows a number of small abyssal hills closely surrounding the site. The seismic profile indicates that the site is actually on a very broad hill, so the best interpretation of the Gloria data (Fig. 20) is that the bright areas seen there represent either small hills or ridges superimposed on the broad one (which is not seen because of its low slope).

The nearest of these ridges, less than $2 \mathrm{~km}$ away to the northeast of the site, is very small and covered with sediment. A much larger ridge ( $15 \mathrm{~km}$ long, $2 \mathrm{~km}$ wide) has its southern end $2 \mathrm{~km}$ northwest of the site. Basement outcrops along an east-facing fault scarp along the entire eastern edge of this ridge. As at Site 559, the whole area is characterized by hills trending east-northeast that were formed as fault blocks striking parallel to the magnetic lineations. However, once again some oblique outcrops trending east-northeast attest to the existence of oblique spreading or short-offset fracture zones in the area. The nearest of these oblique trending out- crops are $50 \mathrm{~km}$ northeast and $65 \mathrm{~km}$ southeast of Site 562. There is no evidence of nonlineated volcanic massifs in this region.

\section{Sites 563/564}

The preliminary location of Site 563 was based on the Vema $(V 17-13)$ seismic and magnetic data. The Challenger seismic data collected in transit from Sites 562 and 563 (Fig. 5) indicated a normal tectonic setting. The limited magnetic data in the area give a strike of about $10^{\circ}$, which is consistent with an orthogonal spreading system. These sites were not surveyed by Gloria.

\section{CONCLUSIONS}

With the exception of Site 557, which intentionally drilled on a smoothed-floor basin, most of the sites meet the criteria of being located on typical ocean basement. Site 558, which had the most complex chemical signature of any site during the cruise, also had the most complex tectonic fabric. In particular, the ocean base- 


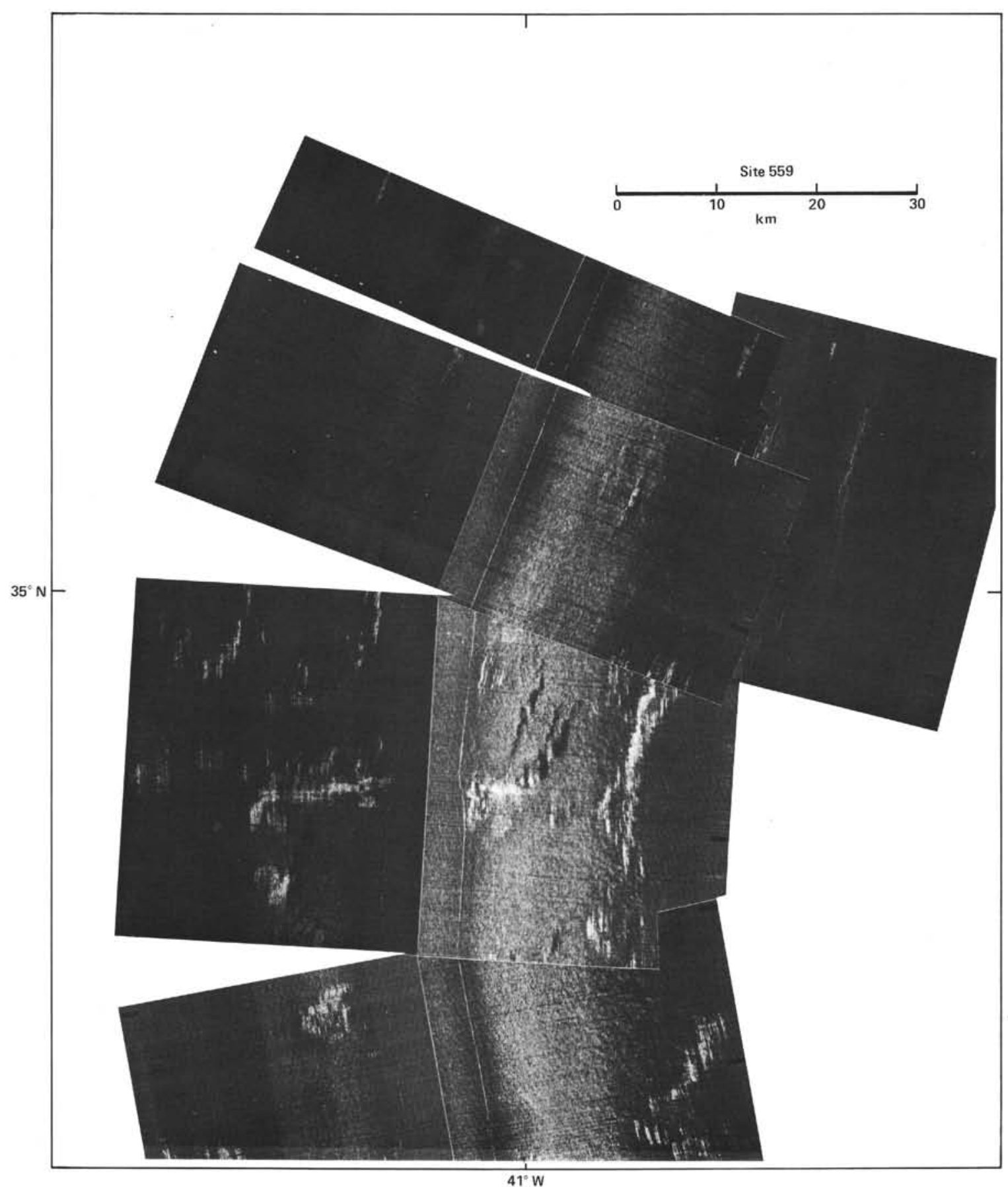

Figure 16. Montage of original Gloria records near Site 559.

ment trends are varying and, in general, oblique to the ridge. Although this site is located $75 \mathrm{~km}$ south of the Pico Fracture Zone, its tectonic character still seems to be under the influence of the fracture zone. Within 15 $\mathrm{km}$ of Site 561, which like Site 558 had both depleted and enriched basalts, there are oblique basement trends. These results suggest that the complexity of the chemical variations found at these sites may be related to local tectonic events, particularly a tendency to oblique spreading, rather than to a regional geochemical phenomenon.

\section{ACKNOWLEDGMENTS}

We thank Willem van der Linden for the use of his geophysical data near Site 558. Hans Schouten and Phil Rabinowitz kindly provided preliminary copies of the magnetic and bathymetric maps from Ocean Margin Drilling Area 11 before the cruise. The scientists and crew of Farnella Cruises 3 and 4/81, particularly Mike Somers and Jack Revie, are thanked for their help with the Gloria surveys.

\section{REFERENCES}

Atwater, T., 1979. Constraints from the FAMOUS area concerning the structure of the oceanic section. In Talwani, M., Harrison, C. G., 
and Hayes, D. E. (Eds.), Deep Sea Drilling Results in the Atlantic Ocean: Ocean Crust: Washington (Am. Geophys. Union), Maurice Ewing Series, 2: 33-42.

LaBrecque, J. L., Kent, D. V., and Cande, S. C., 1977. Revised magnetic polarity time scale for late Cretaceous and Cenozoic time. Geology, 5:330-335.

Laughton, A. S., and Searle, R. C., 1979. Tectonic processes on slow spreading ridges. In Talwani, M., Harrison, C. G., and Hayes, D. E. (Eds.), Deep Drilling Results in the Atlantic Ocean: Ocean Crust: Washington (Am. Geophys. Union), Maurice Ewing Series, 2:15-32.

Phillips, J. D., Fleming, H. S., Feden, R. H., King, W. E., Perry, R. K., 1975. Aeromagnetic survey of the Mid-Atlantic Ridge near the
Oceanographer Fracture Zone. Geol. Soc. Am. Bull., 86:13481357.

Searle, R. C., 1979. Side-scan sonar studies of North Atlantic fracture zones. J. Geol. Soc., London, 136:283-292.

Searle, R. C., and Laughton, A. S., 1977. Sonar studies of the MidAtlantic Ridge and Kurchatov Fracture Zone. J. Geophys. Res., 82:5313-5328.

Vogt, P. R., and Johnson, G. L., 1975. Transform faults and longitudinal flow beneath the Midoceanic Ridge. J. Geophys. Res., 80: 1399-1328.

Date of Initial Receipt: 27 February 1984

Date of Acceptance:13 June 1984

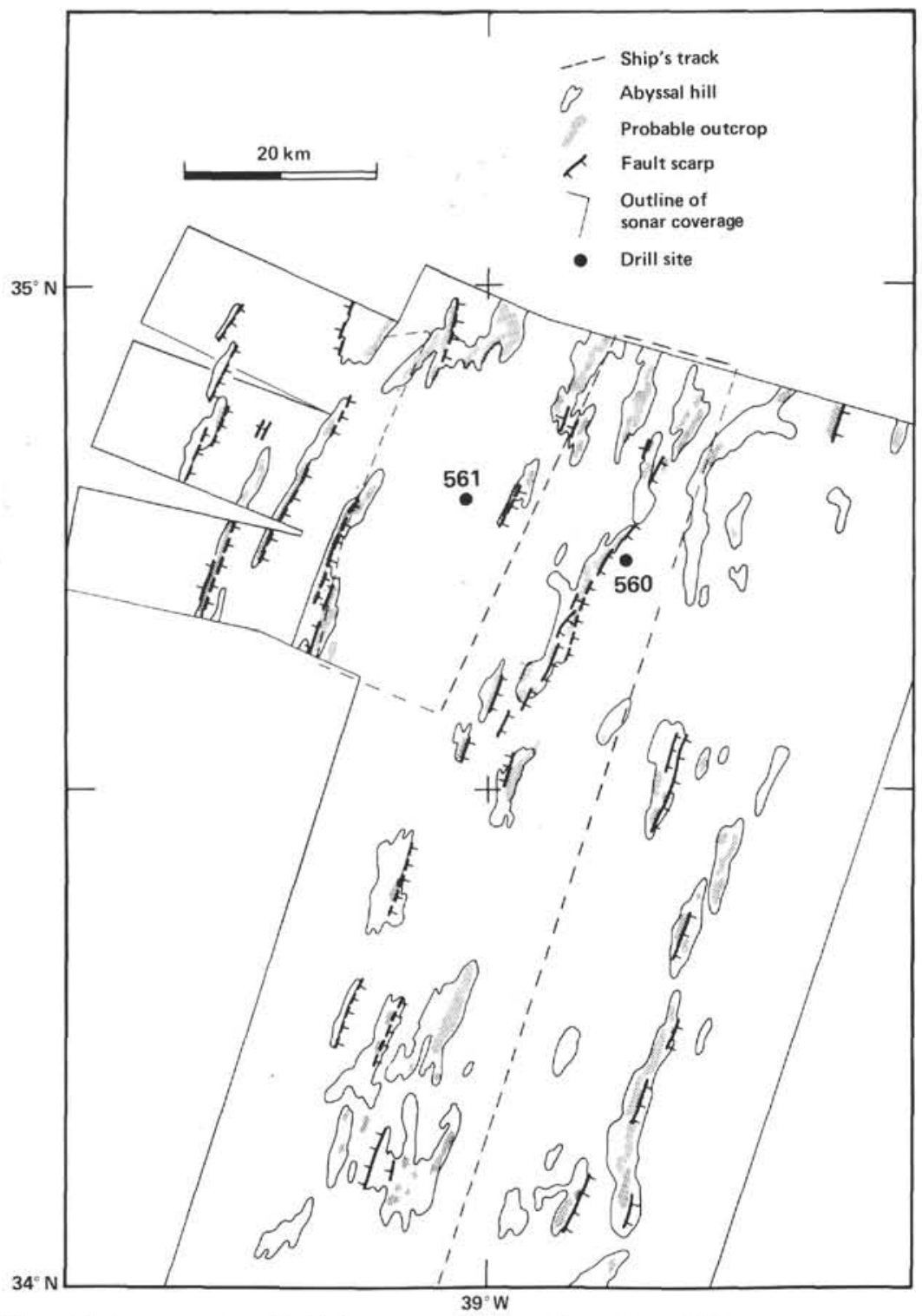

Figure 17. Interpretation of Gloria sonographs near Sites 560 and 561. 


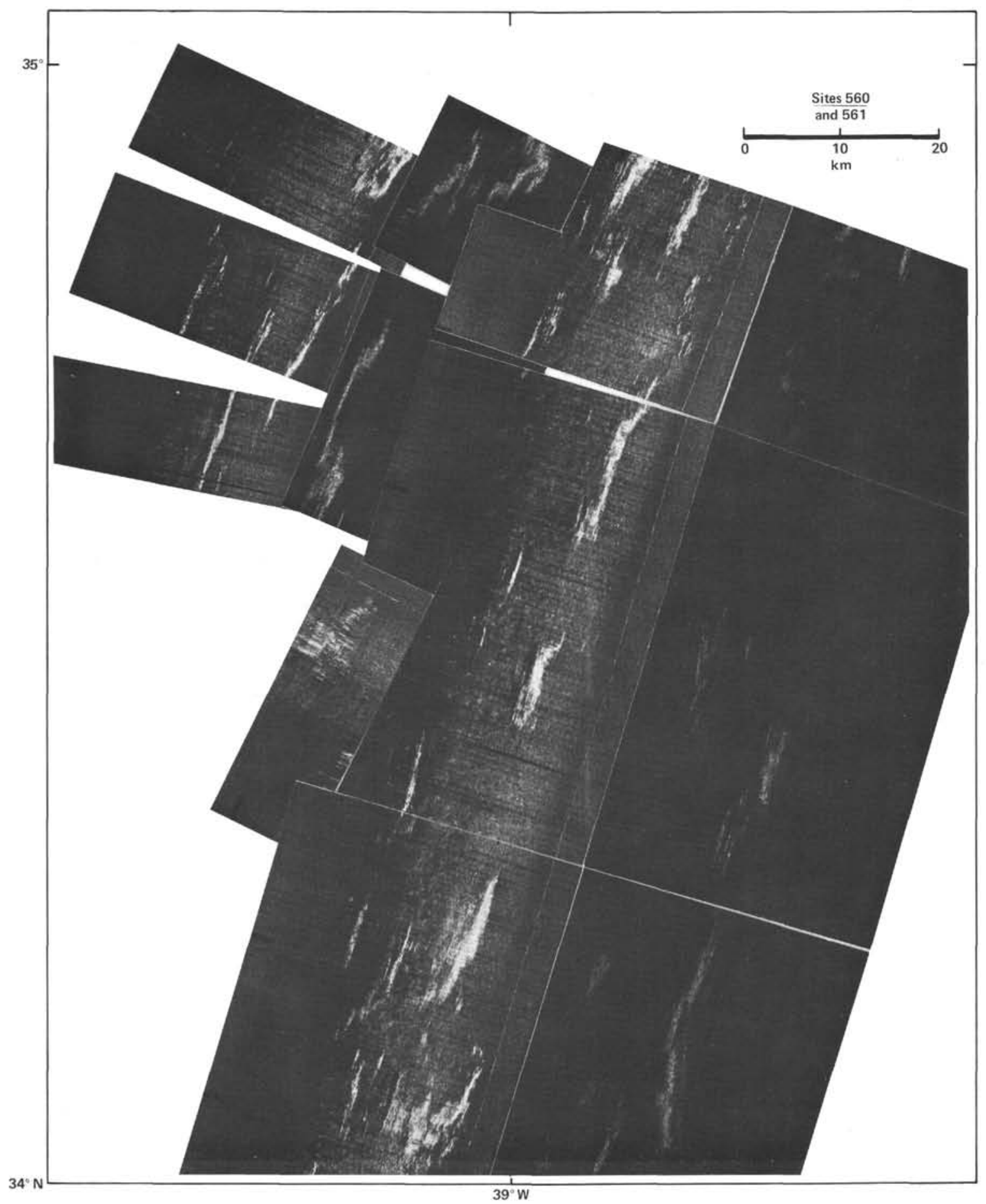

Figure 18. Original Gloria records near Sites 560 and 561. 


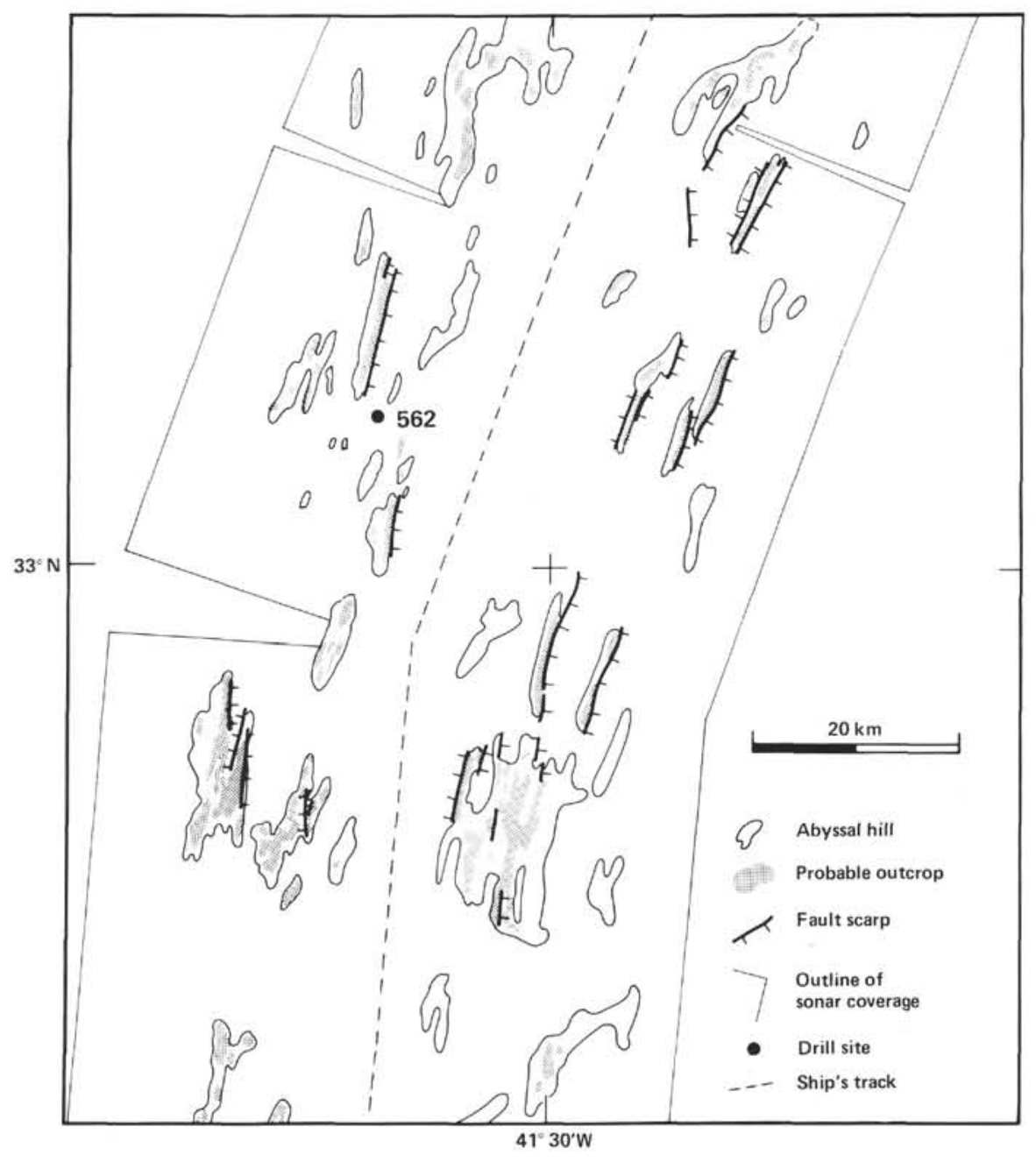

Figure 19. Interpretation of Gloria sonographs near Site 562. 
TECTONIC FABRIC OF THE SEAFLOOR

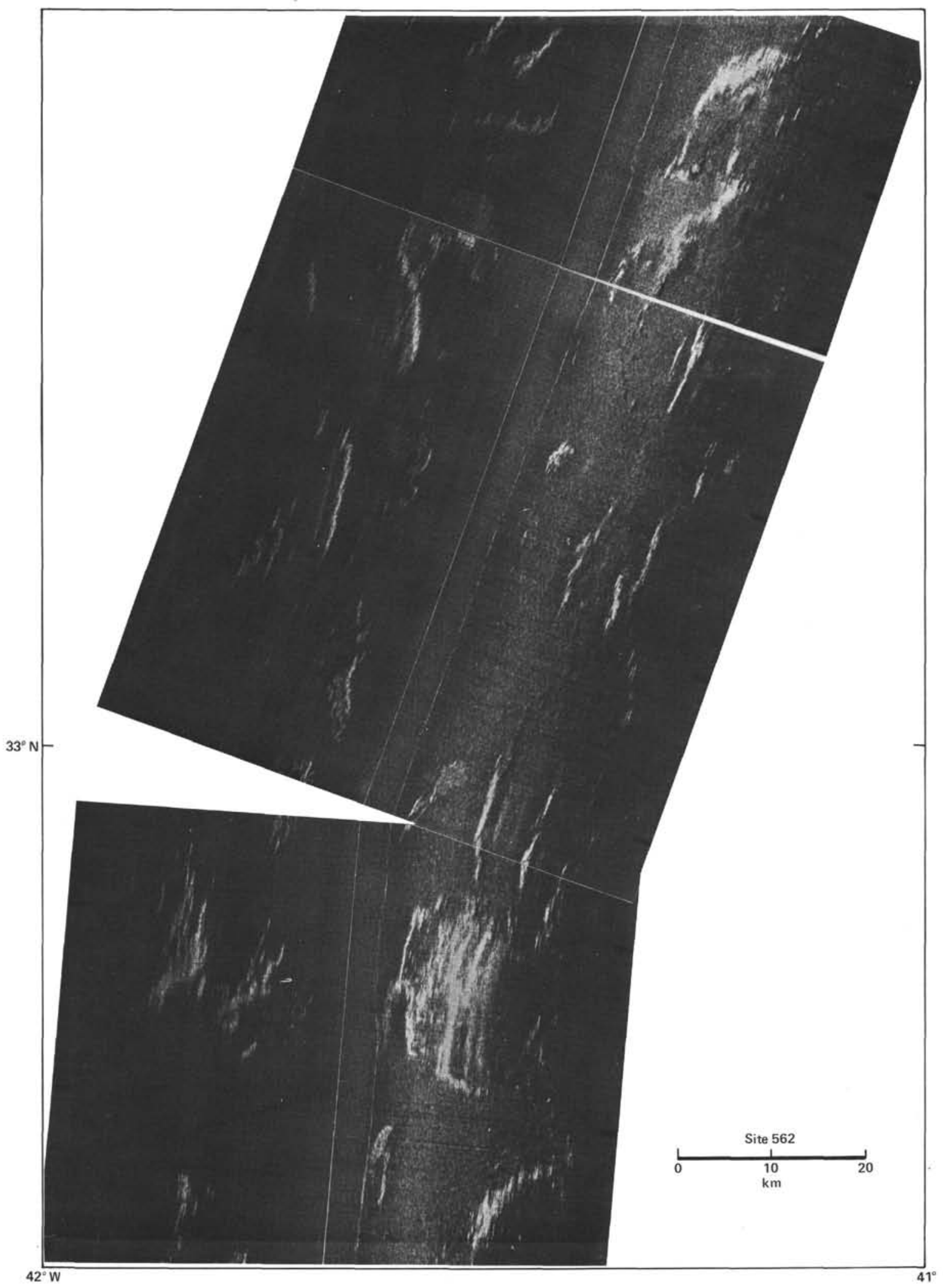

Figure 20. Original Gloria records near Site 562. 